https://doi.org/10.52240/1857-2367.2020.2(21).44

\title{
CERCETAREA PROPRIETĂŢILOR FIZICE ALE PLANTELOR DE ANGHINARE, (CYNARA CARDUNCULUS L.) ȘI CALITĂȚII FURAJULUI PRODUS ÎN REPUBLICA MOLDOVA
}

\author{
Mihai GADIBADI I,2, Victor ȚIȚTEI ${ }^{1}$, Valerian CEREMPEI, ${ }^{1,2}$, Dragoș COVALCIUC ${ }^{1}$, \\ Sergiu COȘMAN ${ }^{1,3}$, Valentina COȘMAN ${ }^{1,3}$, Andrei GUDIMA ${ }^{2}$ \\ 'Grădina Botanică Națională (Institut) „,Al. Ciubotaru”, \\ Chişinău, Republica Moldova \\ ${ }^{2}$ Universitatea Agrară de Stat din Moldova, \\ Chişinău, Republica Moldova \\ ${ }^{3}$ Institutul de Biotehnologii în Zootehnie și Medicină Veterinară, \\ Chişinău, Republica Moldova
}

\begin{abstract}
The objective of this research was to evaluate some physical properties of the seeds and chopped green mass from Cynara cardunculus L., the biochemical composition and feed value of silage obtained in the Republic of Moldova.
\end{abstract}

Key words: Cynara cardunculus, feed value of silage, friability of seeds, particle size distribution of chopped green mass

Anghinarea, Cynara cardunculus L. este o specie erbacee perenă din familia Asteraceae, originară din regiunea Mării Mediterane și nordul Africii, cultivată pe suprafețe mari în Italia, Spania, Franța, S.U.A., Argentina, ca plantă medicinală, alimentară, meliferă, furajeră și energetică. În primul an, planta dezvoltă o rozetă de frunze bazale, iar în al doilea an formeză tulpini viguroase, ramificate în partea superioară, înalte până la 2 $\mathrm{m}$, acoperite cu numeroşi peri albi-cenuşii; frunzele sunt mari, de obicei spinoase, adânc divizate, de culoare verde, albicioasă pe faţa superioară şi alb-cenuşie pe cea inferioară, acoperită cu numeroşi peri, florile, de culoare albastru-violaceu sau roşie-violaceu sunt dispuse în vârful fiecărei ramuri în capitule mari, globuloase, acoperite de solzi groşi, cărnoşi la bază, fructele sunt achene cenușii-întunecate.

Cunoaşterea proprietăților fizice ale semințelor are importanţă deosebită în gestionarea operaţiilor tehnologice de condiţionare post recoltare (curăţire, calibrare, uscare, tratare), încorporare a semințelor în sol, dezvoltării și productivităţii plantelor.

Revitalizarea sectorului de creștere a animalelor necesită diversificarea surselor de producere a furajelor vegetale cu conţinut optimal de nutrienți pe parcursul anului.

Obiectul cercetărilor - semințe și material vegetal de anghinare, Cynara cardunculus colectat din sectorul experimental al Grădinii Botanice, Chişinău (N 46 58'25.7" latitudine și E 28 $52^{\prime} 57.8^{\prime \prime}$ longitudine). La finele vegetației capitulele au fost recoltate și extrase manual semințele. Masa verde a fost colectată la inițierea perioadei de înflorire și prelucrată la tocătorul staționar de furaje. Distribuția fracțională a semințelor și a materialului vegetativ tocat s-a realizat prin cernere cu site oscilante. Determinarea unghiului taluzului natural $\alpha$ a fost realizată prin formarea unei grămezi de seminţe cu forma conică, care se obţine prin cădere liberă a acestora printr-o pâlnie pe o suprafaţă orizontală, iar unghiul de curgere $\alpha_{1}$ a fost măsurat cu ajutorul unei mese cu suprafaţa superioară rotativă în plan vertical. Pregătirea silozului și evaluarea calității lui s-a realizat în conformitate cu standardul SM108 [1]. 
S-a stabilit că semințele de anghinare au unghiul de taluz natural $\alpha=30,3^{0} \pm 1,5^{0}$ și un nivel optimal al friabilității ce permite o distribiție și încorporare uniformă a lor în sol. Plantele colectate la inițierea perioadei de înflorire ating înalțimea de $158-170 \mathrm{~cm}$ și dametrul la bază de 19-23 mm. La trecerea prin tocător s-a observat că tulpinile au un grad ridicat de umiditate și de fibre fine, fapt ce se răsfrânge asupra omogenității masei tocate. S-a determinat că masa tocată conține $26,3 \%$ particule cu dimensuni mai mari de $16,0 \mathrm{~mm}, 54,9 \%$ particule de 8,0-16,0 mm, 17,0 \% particule de 3,15-8,0 $\mathrm{mm}$ și 1,8\% particule mai mici de $3,15 \mathrm{~mm}$. Silozul obținut din masa tocată de anghinare se caracterizează printr-o densitate specifică de $250 \mathrm{~g} / 1$ substanță uscată, la deschidere nu s-au eliminat gaze și suc, culoarea masei conservate este omogenă măslinie, aromă specifică de legume murate, cu aciditatea activă $\mathrm{pH}=3,8$. Concentrația acizilor organici în substanța uscată constituie 4,31\%, inclusiv: $3,42 \%$ acid lactic, $0,75 \%$ acid acetic, prezenți predominant în stare fixată, fapt ce contribie mai accentuat la valorificarea substanțelor nutritive din nutreț. Compoziția biochimică și valoarea furajeră a silozului de anghinare include: $12,5 \%$ proteină brută, $28,0 \%$ celuloză, $22,5 \%$ hemiceluloză, $8,4 \%$ substanțe minerale, $651 \mathrm{~g} / \mathrm{kg}$ substanță digestibilă și o încărcătură de $10,5 \mathrm{MJ} / \mathrm{kg}$ energie metabolizantă.

Semințele de Cynara cardunculus au un nivel optimal de friabilitate și pot fi încorporate în sol cu utilizarea sămănătorilor pentru culturile tradiţionale. Plantele de anghinare pot fi recoltate la inițierea perioadei de înflorire și valorificate în rațiile animalelor de fermă, silozul produs se caracterizează printr-un conținut optimal de proteină, digestibilitate și energie metabolizantă.

Cercetările au fost realizate cu suportul ANCD în cadrul proiectului „, Mobilizarea resurselor genetice vegetale, ameliorarea soiurilor de plante, valorificarea lor ca culturi furajere, melifere și energetice în circuitul bioeconomic”, cifrul 20.80009.5107.02

\section{BIBLIOGRAFIE}

1. SM 108:1995 (1996). Siloz din plante verzi. Condiţii tehnice. Moldovastandart, 10. 